\title{
Pengaruh Endorser terhadap Purchase Intention dengan Perceived Value dan Perceived Usefulness sebagai Variabel Mediasi (Studi Pada Viewer Food Vlogger of YouTube Channel)
}

\author{
Dyajeng Puteri Woro Subagio*, Dwita Laksmita Rachmawati \\ Program Studi Manajemen Fakultas Ekonomi, Universitas Merdeka Pasuruan, Indonesia \\ *dyajengsubagio@gmail.com
}

\begin{abstract}
The main objective of this study is to investigate, describe and analyze the direct and indirect effect of endorsing, perceived value, and perceived usefulness on purchase intention. Statistical population of the present study is all viewer five food vloggers with the most subscribers on YouTube channel in Indonesia. This study uses questionnaires as the research instrument with 200 respondents as the sample. Sampling technique is purposive sampling. This study uses Partial Least Square (PLS) to analyze the data. The result shows there is a significant direct effect of endorser credibility on perceived value and perceived usefulness. In addition, perceived value and perceived usefulness have a significant influence on purchase intention. This study also confirms that perceived value and perceived usefulness mediates the influence of endorser credibility on purchase intention. However, the other result shows that there is no significant relationship between endorser credibility of food vlogger on purchase intention. Distance and price are the main reasons customer has no purchase intention of food product that has been reviewed by endorsers.
\end{abstract}

Keywords: Endorser, Perceived Value, Perceived Usefulness, Purchase Intention

\section{PENDAHULUAN}

Indonesia adalah negara yang mempunyai berbagai macam adat, budaya berserta kulinernya. Keberagaman jenis kuliner hampir tersebar di seluruh kota maupun pelosok daerah di Indonesia. Industri kuliner menjadi sangat menjanjikan bagi para pengusaha makanan. Di sisi lain, perkembangan industri makanan di Indonesia memunculkan sebuah tantangan yang harus dihadapi oleh pelaku bisnis dalam merebut dan mempertahankan pangsa pasar. Hal ini mendorong pengusaha kuliner untuk dapat mengenalkan dan mempromosikan tentang produknya kepada masyarakat di tengah persaingan yang ketat. Periklanan merupakan salah satu strategi pemasaran yang umum digunakan oleh pelaku bisnis. Keller (2008) berpendapat bahwa periklanan merupakan bagian dari komunikasi non personal yang digunakan pelaku bisnis untuk memberikan informasi produk yang bersifat persuatif kepada konsumen dan target pasar. Iklan dapat dikatakan baik apabila memiliki daya tarik tertentu sehingga mampu mengikat perhatian pasar serta dapat membentuk kepercayaan konsumen. Strategi periklanan yang banyak digunakan oleh pelaku bisnis saat ini adalah penggunaan YouTuber sebagai endorser. Endorser dapat diartikan sebagai seseorang yang memiliki ketenaran di kalangan publik serta memanfaatkannya untuk mempromosikan suatu produk (Kok Wei \& Li, 2013; Kim et al., 2014). Strategi 
endorsement mempunyai efek yang positif dalam mempromosikan suatu produk yang diyakini mampu mempermudah konsumen dalam mengingatnya (Ohanian, 1990).

Platform online yang sangat populer di Era Revolusi Industri 4.0 salah satunya adalah YouTube. YouTube memperoleh prosentase $49 \%$ sebagai social media yang sering digunakan di Indonesia (We Are Social and Hootsuite, 2017). Selanjutnya, Google mengungkapkan bahwa $57 \%$ pengguna YouTube menggunakan aplikasi tersebut sebagai konten hiburan, serta $86 \%$ menggunakan YouTube sebagai media untuk mencari informasi baru (https://id. techinasia.com/).

Kehadiran food vlogger sebagai celebrity YouTube berpengaruh besar pada industri makanan di Indonesia. Keberadaan mereka membantu para pengusaha kuliner di Indonesia untuk mempromosikan produk makanan atau minumannya kepada masayarakat luas melalui media YouTube. Hasil ulasan mereka tentang makanan yang telah dicoba akan dijadikan pertimbangan masyarakat atau konsumen dalam melakukan keputusan pembelian terhadap makanan. Hal ini juga mempermudah masyarakat atau konsumen untuk memperoleh informasi maupun rekomendasi kuliner yang akan mereka beli.

Efektivitas endorsement dipengaruhi oleh kredibilitas endorser dalam menyampaikan pesan. Hal ini bergantung pada attractiveness, trustworthiness dan level of expertise dari seorang endorser (Ohanian, 1990). Attractiveness mengacu pada daya tarik fisik seseorang, misalnya kecantikan, keeleganan, sikap, dan etika (Amos et al., 2008 ; Han \& Ki, 2010). Trustworthiness berkaitan dengan derajat kepercayaan penerima informasi pada kemampuan endorser untuk menyampaikan informasi yang jujur dan dapat dipercaya (Erdogan et al., 2001). Sedangkan expertise mengacu pada sejauh mana kemampuan dan pengalaman seorang dapat membantu konsumen dalam proses pengambilan keputusan (Amos et al., 2008). Persepsi konsumen akan endorser yang kredibel mampu medorong terbentuknya minat beli (purchase intention) (Roy, 2018; Sertoglu et al., 2014; Gupta et al., 2015; Qureshi \& Malik, 2017; Mohd, 2016). Pada penelitian perilaku pembelian, purchase intention didefinisikan sebagai minat konsumen untuk membeli produk di masa yang akan datang (Hsu \& Tsou, 2011; Saxena, 2011). Purchase intention dapat digunakan untuk memprediksi perilaku pembelian yang nyata (Hsu \& Tsou, 2011).

Kredibilitas yang dimiliki oleh endorser secara implisit akan membentuk suatu image atau citra atas produk sehingga mampu meningkatkan atau menurunkan value dari suatu produk yang dipasarkan. Hal ini sejalan dengan hasil penelitian Chi et al., (2011); Ohanian (1990); Renton \& Renton (2006) yang menyebutkan bahwa endorser credibility berpengaruh signifikan terhadap perceived value dari suatu produk tertentu. Kotler \& Keller (2009) menyatakan bahwa customer perceived value adalah selisih antara penilaian pelanggan prospektif atas perceived usefulness dan price dari suatu penawaran terhadap alternatifnya. Dengan kata lain, nilai dari sebuah produk akan meningkat apabila sesuai dengan keinginan, kebutuhan serta permintaan konsumen. Selain itu, endorser yang kredibel mampu meningkatkan persepsi manfaat (perceived usefulness) yang dirasakan konsumen (McKnight et al., 2003; Mir \& Rehman, 2013; Wang et al., 2003). Perceived usefulness adalah sejauh mana seseorang percaya bahwa menggunakan suatu sistem atau teknologi akan meningkatkan kinerjanya dalam mendapatkan suatu informasi tertentu (Thompson et al., 1991).

Terdapat banyak food vlogger yang memliki channel dengan konten kuliner. Beberapa diantaranya telah memiliki pengikut atau subscriber lebih dari 1 juta. Artinya mereka telah menjadi sosok yang populer di kalangan masyarakat dan diharapkan mampu menjadi influencer bagi masyarakat khususnya di bidang kuliner. Berikut 5 food vlogger dengan subscriber terbanyak di YouTube: 
Tabel 1. Lima Food Vlogger dengan Subscriber Terbanyak di YouTube

\begin{tabular}{llcc}
\hline No & $\begin{array}{c}\text { Nama Food } \\
\text { Vlogger }\end{array}$ & $\begin{array}{c}\text { Jumlah } \\
\text { Subscriber }\end{array}$ & $\begin{array}{c}\text { Jumlah } \\
\text { Viewer }\end{array}$ \\
\hline 1 & Tanboy Kun & 2.589 .116 & 316.977 .476 \\
2 & Ria SW & 2.400 .848 & 371.913 .390 \\
3 & Mgdalenaf & 1.189 .016 & 133.618 .184 \\
4 & Ken \& Grat & 1.170 .460 & 218.318 .544 \\
5 & Nex Carlos & 1.152 .550 & 153.674 .898
\end{tabular}

Sumber: (https://www.youtube.com/, diakses 4 Mei 2019)

Keahlian dan kejujuran para food vlogger diatas dalam melakukan review dan memberikan segala informasi mengenai kuliner yang mereka coba, membawa banyak manfaat bagi pelaku industri kuliner di Indonesia. Kredibilitas dan kepopuleran seorang YouTuber akan mendorong perusahaan untuk menggunakan strategi endorsement. Pemilihan para YouTuber tersebut sebagai endorser dirasa mampu meningkatkan penjualan produk. Beberapa penelitian menyebutkan bahwa seseorang cenderung akan membeli dan mengkonsumsi produk yang di konsumsi atau di endorse oleh selebriti favoritnya (Dhar \& Khan, 2006; Wilcox et al., 2011; Wilcox \& Stephen, 2013),

Mengacu pada latar belakang dan fenomena bisnis tersebut, endorser memiliki peranan penting bagi konsumen dengan memberikan suatu arahan dalam menentukan keputusan pembeliannya. Namun peranan endorser dalam mempengaruhi minat beli konsumen perlu dikaji sebab konsumen pada umumnya akan melakukan penilaian terhadap produk sehingga terbentuk perceived value akan sebuah produk dan perceived usefulness dari penggunaan suatu teknologi yang mempengaruhi purchase intention. Oleh karena itu, penelitian ini bertujuan untuk menguji peranan langsung variabel endorser terhadap purchase intention serta untuk mengetahui apakah varibel endorser akan membentuk varibel perceived value dan perceived usefulness terlebih dahulu yang selanjutnya berpengaruh terhadap variabel purchase intention pada produk makanan yang telah diulas oleh food vlogger pada channel YouTube.

\section{Endorser}

Endorser merupakan individual yang dinilai menarik oleh publik dan dapat digunakan oleh kegiatan pemasaran untuk mengiklankan produk terhadap konsumen. Sosok endorser seperti ini bisa berasal dari kalangan selebriti ataupun non selebriti. Endorser dimaksudkan untuk menyampaikan pesan kepada konsumen mengenai produk (Belch \& Belch, 2013). Pemilihan selebriti sebagai endorser memerlukan pertimbangan, sebab karakteristik endorser berpengaruh pada efektifitas dalam menaikkan brand awareness dan citra produk (Royan, 2005).

Credibility merupakan hal yang harus diperhatikan dari seorang endorser. Semakin tinggi kredibilitas endorser, maka efektivitas penyampaian promosi akan semakin besar (Wang et al., 2003). Efektivitas seorang endorser dalam menyampaikan pesan bergantung pada attractiveness, trustworthiness dan level of expertise dari seorang endorser (Ohanian, 1990).

\section{Perceived Value}

Perceived value mencerminkan hubungan antara konsumen dengan produk. Customer perceived value merupakan selisih antara penilaian pelanggan prospektif atas perceived usefulness dan price dari suatu penawaran terhadap alternatifnya (Kotler \& Keller, 2009). Perceived value terbentuk dari pengetahuan yang didapatkan dan diharapkan konsumen serta apa yang diterima. Konsumen akan membandingkan persepsi kualitas terhadap produk dengan pengorbanan yang dilakukan untuk mendapatkan produk tersebut.

Perceived value digunakan konsumen untuk mempertimbangkan aspek layanan dan biaya yang ditawarkan beberapa produk pesaing. Tingginya perceived value terhadap suatu produk akan menimbulkan minat beli (purchase intention) pada diri konsumen (Chi et al., 2011).

Mohammad (2012) berpendapat terdapat tiga indikator perceived value yaitu: menawarkan nilai yang baik (offer good value), harga yang pantas (worth price), kelayakan (appropriatesness), kesesuaian 
harga dengan produk yang ditawarkan (suit price).

\section{Perceived Usefulness}

Frekuensi penggunaan teknologi bergantung pada manfaat yang dirasakan oleh penggunanya. Kepercayaan seseorang dalam penggunaan sistem atau teknologi tertentu dapat meningkatkan kinerjanya merupakan pengertian dari perceived usefulness (Thompson et al., 1991). Dengan kata lain, perceived usefulness terhadap suatu teknologi informasi merupakan manfaat yang diharapkan oleh pengguna dalam mendapatkan sesuatu. Seseorang akan cenderung melakukan penggunaan berulang pada teknologi apabila merasakan suatu kemudahan (perceived ease of use) (Subagio et al., 2018).

Produk yang disampaikan oleh endorser pada channel YouTube akan mempermudah seseorang dalam memperoleh informasi dan rekomendasi akan suatu produk. Pavlou \& Fygenson (2006) mendefinisikan perceived usefulness sebagai informasi dari jejaring internet atau website yang dipercayai dapat meningkatkan efisiensi dalam memperoleh informasi produk. Berdasarkan Technology Acceptance Model (TAM), perceived usefulness dapat mempengaruhi sikap konsumen (Mir \& Rehman, 2013). Perceived usefulness yang dirasakan oleh seseorang dari perekomendasian pada website akan mempengaruhi minat beli konsumen (Hsu \& Tsou, 2011). Pada penelitian yang dilakukan oleh Yuksel (2016), terdapat empat indikator yang digunakan untuk mengukur perceived usefulness diataranya: meningkatkan nilai (improves value), meningkatkan produktivitas (increase productivity), meningkatkan efektivitas (enhance effectiveness), kemanfaatan sistem (the system is usefull).

\section{Puchase Intention}

Purchase intention merupakan kecenderungan minat konsumen terhadap suatu produk dan kemungkinan untuk membelinya. Purchase intention dapat diartikan pula sebagai minat konsumen untuk melakukan pembelian produk di masa yang akan datang (Hsu \& Tsou, 2011; Saxena, 2011). Minat seseorang dapat tercermin melalui penilaian terhadap sebuah produk. Ketika timbul minat seseorang akan memiliki dorongan psikologis yang sangat kuat untuk melakukan sesuatu kegiatan. Kaitannya dengan pemasaran, minat konsumen terhadap suatu produk berpengaruh besar terhadap keputusan pembelian yang akan dilakukan. Oleh karenanya, purchase intention dapat digunakan untuk memprediksi perilaku pembelian yang nyata (Hsu \& Tsou, 2011).

Berdasarkan uraian di atas, penelitian ini bertujuan untuk menguji apakah Endorser (X1) berpengaruh pada Perceived Value (Z1), Perceived Usefulness (Z2), dan Purchase Intention (Y). Selajutnya akan dilakukan pengujian apakah perceived value dan perceived usefulness mampu memediasi hubungan antara varibel endorser dengan purchase intention. Adapun kerangka konseptual dalam penelitian ini dapat dilihat pada gambar 1 berikut ini.

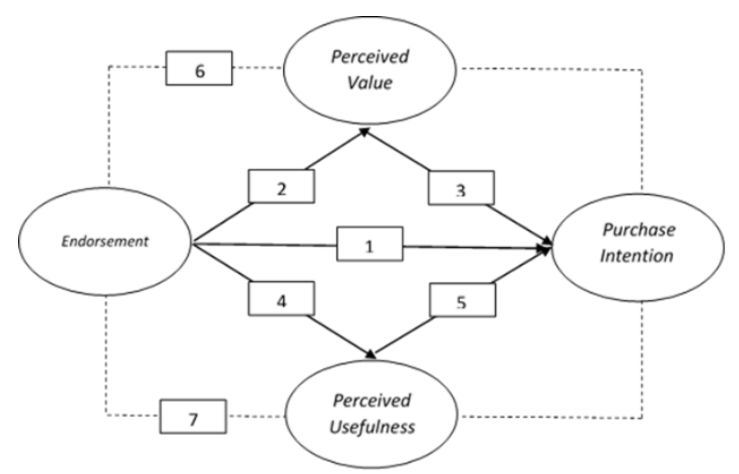

Gambar 1 : Kerangka Konseptual

Sumber: Dikembangkan oleh peneliti (2019)

\section{Hipotesis}

Berdasar uraian berkaitan dengan hasil penelitian-penelitian di atas maka hipotesis dalam penelitian ini adalah:

$\mathrm{H}_{1}$ : Endorser berpengaruh pada purchase intention

$\mathrm{H}_{2}$ : Endorser berpengaruh pada perceived value

$\mathrm{H}_{3}$ : Perceived value berpengaruh pada purchase intention

$\mathrm{H}_{4}$ : Endorser berpengaruh pada perceived usefulness 
$\mathrm{H}_{5}$ : Perceived usefulness berpengaruh terhadap purchase intention

$\mathrm{H}_{6}$ : Perceived value memediasi hubungan endorser terhadap Purchase Intention

$\mathrm{H}_{7}$ : Perceived usefulness memediasi hubungan endorser terhadap Purchase Intention

\section{METODE}

Penelitian ini merupakan explanatory research yang dilakukan pada bulan Mei s.d. November 2019. Penelitian ini dilakukan dengan menyebar kuesioner secara online. Populasi merupakan seluruh viewer atau penonton pada channel YouTube kuliner Tanboy Khun, Ria SW, Mgdalenaf, Ken \& Grat, dan Nex Carlos di seluruh Indonesia. Teknik sampling yang digunakan adalah non probability sampling dengan pendekatan purposive sampling dengan kriteria yaitu: 1) Responden memiliki account pada YouTube; 2) Responden merupakan viewer pada channel YouTube kuliner Tanboy Khun, Ria SW, Mgdalenaf, Ken \& Grat, atau Nex Carlos; 3) Responden merupakan subscriber pada channel YouTube kuliner Tanboy Khun, Ria SW, Mgdalenaf, Ken \& Grat, atau Nex Carlos. Metode analisis yang digunakan adalah PLS (Partial Least Square) dengan alat analisis smartPLS 3.0.

Hair, Jr (2015) menyatakan bahwa ukuran sampel tergantung pada jumlah indikator yang digunakan pada seluruh variabel laten, sehingga jumlah sampel dapat dihitung dengan mengkalikan 5 sampai dengan 10 jumlah indikator. Jumlah sampel yang dibutuhkan dalam penelitian ini sebesar 140 (14 indikator x $10=140$ responden), namun peneliti menambahkan spare sebesar $40 \%$ dari jumlah tersebut menjadi sebanyak 196 responden, yang kemudian dibulatkan menjadi 200 responden. Ukuran sampel ini sudah sesuai dengan pedoman ukuran sampel mengikuti teknik maximum likehood estimation yang menyatakan ukuran sampel antara 100-200 responden (Ferdinand, 2016)

\section{HASIL DAN PEMBAHASAN}

Berdasar hasil survei, dari 200 responden yang mengisi kuesioner penelitian ini secara online, $60,5 \%$ responden berpendapat bahwa Nex Carlos merupakan food vlogger yang memiliki kredibilitas tinggi dalam mengulas makanan sehingga dapat dijadikan alternatif rekomendasi makanan.

Hasil analisis outer model pada penelitian ini menunjukkan bahwa semua indikator dikatakan valid dan reliable sebab pada uji validitas konvergen, nilai outer loading pada seluruh item indicator $>0,5$ yang artinya tidak perlu ada item pada kuesioner yang dihilangkan dari model. Begitu pula pada uji validitas diskriminan nilai AVE seluruh konstruk lebih besar dari korelasi variabel laten. Lebih lanjut pada uji reliabilitas dikriminan, konstruk pada variabel endorser, perceived value, perceived usefulness, dan purchase intention menunjukkan nilai composite reliability > 0,70 nilai cronbach alpha $>0,60$ dari seluruh konstruk, begitu juga dengan nilai AVE seluruh konstruk $>0,50$, sehingga dapat dinyatakan bahwa keseluruhan konstruk telah memenuhi syarat reliabilitas.

Model struktural pada penelitian ini mempunyai nilai Goodness of Fit (GoF) sebesar 0,502 secara umum mempunyai sifat prediksi yang bagus (GoF large) (Ghozali dan Latan, 2012), artinya model tersebut mempunyai kemampuan yang tinggi dalam menjelaskan data empiris. Evaluasi koefisien determinasi (R-Square) menunjukkan bahwa variabel perceived value, perceived usefulness, dan purchase intention mampu dijelaskan oleh variabel endorser sebesar $55,1 \%$; 44,3\%; dan 52,6\%. Selanjutnya pada evaluasi model structural melalui Q-Square didapatkan $88 \%$ variable purchase intention dapat diprediksi oleh varibel endorser, perceived value, dan perceived usefulness.

Software smart PLS 3.0 menunjukkan hasil analisis dari hipotesis masing-masing jalur sebagai berikut: 
Tabel 2. Hasil Analisis Pengujian Hipotesis Pengaruh Langsung

\begin{tabular}{clcc}
\hline Hipotesis & \multicolumn{1}{c}{ Hubungan } & t-hitung & p-values \\
\hline $\mathrm{H}_{1}$ & $\begin{array}{l}\text { Endorser } \rightarrow \\
\text { Purchase } \\
\text { Intention } \\
\mathrm{H}_{2}\end{array}$ & 0,280 & 0,780 \\
& $\begin{array}{l}\text { Endorser } \rightarrow \\
\text { Perceived } \\
\text { Value }\end{array}$ & 15,670 & 0,000 \\
$\mathrm{H}_{3} \quad$ & & \\
& $\begin{array}{l}\text { Perceived } \\
\text { Value } \rightarrow\end{array}$ & & \\
& $\begin{array}{l}\text { Purchase } \\
\text { Intention } \\
\text { Endorser } \rightarrow \\
\mathrm{H}_{4}\end{array}$ & 2,126 & 0,034 \\
& $\begin{array}{l}\text { Perceived } \\
\text { Usefulness } \\
\text { Perceived } \\
\mathrm{H}_{5}\end{array}$ & 9,059 & 0,000 \\
& $\begin{array}{l}\text { usefulness } \rightarrow \\
\text { Purchase } \\
\text { Intention }\end{array}$ & 4,716 & 0,000 \\
& & \\
\hline
\end{tabular}

Sumber: Dikembangkan oleh peneliti, 2019

Hasil pengujian hipotesis menunjukkan $\mathrm{H}_{2}, \mathrm{H}_{3}, \mathrm{H}_{4}, \mathrm{H}_{5}$ mempunyai nilai $t$-statistics $>1.96$ serta nilai $p$-values $<0.05$, sehingga dapat dinyatakan signifikan dan dapat disimpulkan bahwa hipotesis diterima. Berbeda dengan $\mathrm{H}_{1}$, nilai $t$-statistics $<1.96$ dan nilai $p$-values $>0.05$, maka hasilnya dapat dikatakan tidak signifikan sehingga dapat disimpulkan bahwa variabel endorser tidak berpengaruh signifikan terhadap purchase intention. Oleh karena itu, hipotesis 1 dinyatakan ditolak.

Tabel 3 menunjukkan bahwa $\mathrm{H}_{6}$ dan $\mathrm{H}_{7}$ diterima sebab memiliki nilai $t$-statistics $>1.96$ serta nilai $p$-values $<0.05$. Sehingga dapat disimpulkan bahwa perceived value dan perceived usefulness secara signifikan memediasi hubungan endorser terhadap purchase intention.

Tabel 3 Hasil Analisi Pengujian Hipotesis Pengaruh Tidak Langsung

\begin{tabular}{|c|c|c|c|}
\hline Hipotesis & Hubungan & $\begin{array}{c}\mathrm{Z}^{-} \\
\text {value }\end{array}$ & $\begin{array}{c}p- \\
\text { values }\end{array}$ \\
\hline $\mathrm{H}_{6}$ & $\begin{array}{l}\text { Endorser } \rightarrow \text { Perceived } \\
\text { Value } \rightarrow \text { Purchase } \\
\text { Intention }\end{array}$ & 2,058 & 0,040 \\
\hline $\mathrm{H}_{7}$ & $\begin{array}{l}\text { Endorser } \rightarrow \text { Perceived } \\
\text { Usefulness } \rightarrow \text { Purchase } \\
\text { Intention }\end{array}$ & 4,805 & 0,000 \\
\hline
\end{tabular}

Sumber: Data primer diolah, 2019

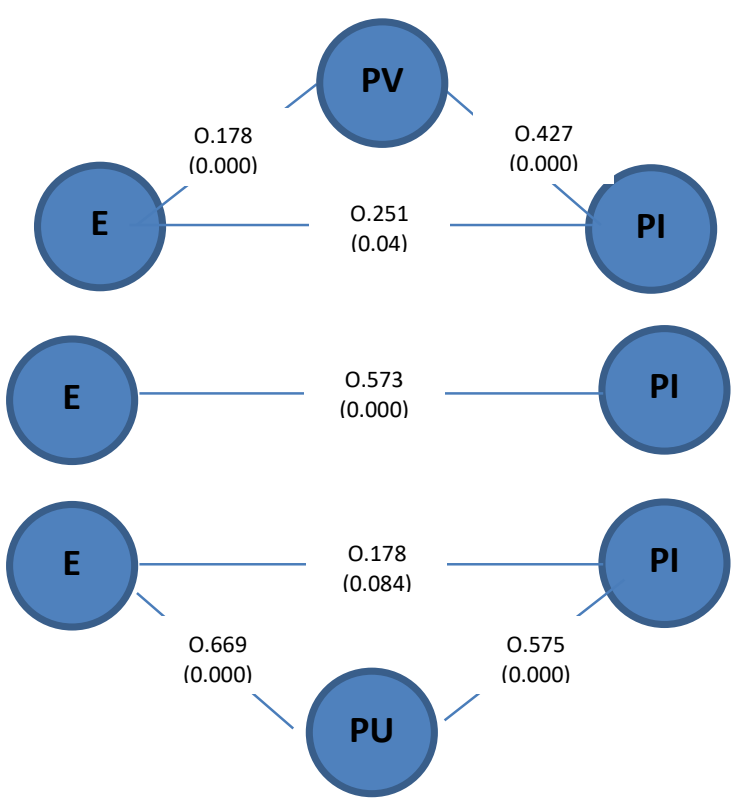

Gambar 2 : Model Direct Effect dan Indirect Effect Peran Mediasi Perceived Value dan Perceived Usefulness

Sumber: Data primer diolah, 2019

Hasil pengujian pada gambar 2 menunjukkan bahwa koefisien direct effect pada endorser terhadap purchase intention (c) adalah 0,573. Koefisien indirect effect (c") dengan variabel mediasi perceived value dan perceived usefulness secara berturut-turut turun menjadi 0,251 namun tetap signifikan dan 0,178 tidak signifikan artinya keduanya mampu memediasi hubungan variabel endorser dan purchase intention. Perceived value bersifat partial mediation atau mediasi parsial karena tetap signifikan. Sedangkan perceived usefulness bersifat full mediation atau mediasi penuh karena berubah menjadi tidak signifikan.

\section{Pengaruh Endorser terhadap Purchase Intention}

Hasil analisis data memperlihatkan bahwa variabel endorser tidak berpengaruh signifikan terhadap variabel purchase intention. Artinya peran endorser atau food vlogger dalam mengulas makanan yang ditayangkan pada akun YouTube mereka tidak signifikan membuat para pengikutnya untuk melakukan pembelian pada makanan yang mereka ulas. Hal ini bertolak belakang 
dengan hasil penelitian Dhar \& Khan (2006); Wilcox et al. (2011); Wilcox \& Stephen (2013) yang menyatakan bahwa seseorang cenderung akan membeli dan mengkonsumsi produk yang di konsumsi atau di endorse oleh selebriti favoritnya. Ada beberapa alasan yang dikemukakan oleh responden mengapa mereka tidak memiliki niat untuk membeli makanan yang diulas oleh food vlogger diantaranya terkait jarak dan harga. Mereka berpendapat bahwa restoran yang dikunjungi oleh para food vlogger dianggap terlalu jauh dengan tempat tinggal mereka. Sedangkan para food vlogger Tanboy Khun, Ria SW, Mgdalenaf, Ken \& Grat, dan Nex Carlos tidak hanya mengulas makanan yang terdapat pada satu wilayah saja akan tetapi di berbagai kota atau kabupaten di Indonesia atau bahkan sampai ke luar negeri. Jarak erat kaitannya dengan faktor distribusi sebagai cara menyalurkan barang agar sampai dan dikonsumsi oleh konsumen. Semakin jauh restoran dengan tempat tinggal konsumen semakin tinggi biaya yang harus dikeluarkan konsumen untuk bisa membeli makanan tersebut diluar harga makanan sesungguhnya. Selain itu, responden mengemukakan bahwa tidak semua makan yang diulas oleh food vlogger memilki harga yang terjangkau bagi mereka. Sehingga jarak dan harga menyebabkan mereka tidak signifikan minat melakukan pembelian pada makanan yang food vlogger atau endorser ulas pada video yang diunggah di YouTube. Hal ini sejalan dengan Gupta et al. (2015) dan Vidyanata et al. (2018) mengatakan bahwa celebrity endorsement tidak signifikan berpengaruh pada purchase intention.

\section{Pengaruh Endorser terhadap Perceived Value}

Kredibilitas food vlogger berpengaruh signifikan terhadap perceived value yang dirasakan oleh penonton YouTube mereka. Attractiveness atau daya tarik fisik, trustworthiness kehandalan dan kejujuran dalam menyampaikan informasi dalam mengulas makanan serta level of expertise kecakapan, pengalaman, pengetahuan yang baik dalam menilai cita rasa makanan dari seorang endorser secara implisit akan membentuk suatu image atau citra atas produk sehingga mampu meningkatkan value produk yang dipasarkan. Hal tersebut sejalan dengan hasil penelitian (Chi et al., 2011; Renton \& Renton, 2006) yang mengemukakan bahwa endorser credibility berpengaruh signifikan terhadap perceived value dari suatu produk tertentu.

\section{Pengaruh Perceived Value terhadap Purchase Intention}

Perceived value yang dirasakan oleh viewer food vlogger berpengaruh signifikan terhadap minat beli konsumen terhadap produk yang ditayangkan di channel YouTube. Hal ini sejalan dengan hasil penelitian yang dilakukan oleh Chi et al. (2011) yang mengemukakan bahwa persepsi nilai yang baik dapat menimbulkan minat beli konsumen.

Penawaran nilai yang tercermin pada kualitas makanan yang ditawarkan oleh food vlogger, kelayakan makanan serta kesesuaian harga dengan produk yang ditawarkan mampu meningkatkan minat konsumen untuk membeli produk tersebut di masa yang akan datang. Oleh karenanya seorang endorser harus pintar dalam memilih makanan yang layak baik dari kualitas dan harga untuk direkomendasikan kepada konsumen. Sebab apabila kualitas atau harga makanan tidak sesuai dengan perceived value yang dirasakan konsumen akan berdampak pada perilaku konsumen di masa akan datang seperti ketidakpuasan konsumen, world of mouth yang negatif, serta berpengaruh terhadap kredibilitas endorser.

\section{Perngaruh Endorser terhadap Perceived Usefulness}

Endorser yang kredibel mampu meningkatkan persepsi manfaat (perceived usefulness) yang dirasakan konsumen. Makanan yang disampaikan oleh food vlogger pada channel YouTube mempermudah reviewer dalam memperoleh informasi dan rekomendasi tentang produk makanan. Dengan kata lain, endorser yang kredibel mampu meningkatkan perceived usefulness 
yang dirasakan konsumen (McKnight et al., 2003; Mir \& Rehman, 2013; Wang et al., 2003).

Penggunaan YouTube sebagai media endorsement dinilai efektif untuk mempromosikan suatu produk. Di Era Revolusi Industri 4.0, perilaku konsumen dalam mencari suatu informasi telah beralih dari media konvensional ke media digital seperti social media salah satunya adalah YouTube. Tayangan video yang diunggah oleh para food vlogger pada YouTube dengan mudah bisa ditonton oleh viewer dan dijadikan rekomendasi makanan oleh konsumen. Konsumen merasakan manfaat dan kemudahan dalam mendapatkan informasi yang diberikan oleh food vlogger. Mereka tidak perlu mencari-cari restoran, mencoba apakah makanan yang ditawarkan restoran tersebut enak atau tidak, apakah layak dimakan atau tidak, selain itu apakah harga yang ditetapkan sebanding dengan kualitas makanan yang dijual. Kredibilitas endorser dalam mengulas makanan dengan jujur akan meningkatkan trustworthiness pada diri konsumen. Sehingga konsumen semakin percaya dan mengganggap bahwa dengan adanya food vlogger sangat bermanfaat guna merekomendasikan makanan-makanan yang ada di Indonesia.

\section{Pengaruh Perceived Usefulness terhadap Purchase Intention}

Persepsi manfaat yang dirasakan oleh konsumen dari menonton video-video ulasan makanan yang ditayangkan para food vlogger pada channel YouTube mereka mampu meningkatkan minat mereka untuk membeli makanan yang telah direkomendasikan di masa yang akan datang. Efektifitas yang dirasakan konsumen dengan menonton YouTube memudahkan mereka dalam memperoleh rekomendasi makanan yang akan mereka beli. Dengan kata lain, biaya yang mereka keluarkan untuk mencari informasi dari suatu produk dapat ditekan dengan adanya aplikasi YouTube. Perbandingan antara manfaat yang mereka terima dengan pengorbanan yang mereka lakukan akan berdampak pada nilai yang mereka rasakan. Oleh karenanya mereka menggap bahwa keberadaan food vlogger sangat bermanfaat dan mampu meningkatkan minat beli mereka terhadap makanan yang sudah direkomendasikan. Hal ini sejalan dengan hasil penelitian Hsu \& Tsou (2011) yang menyatakan bahwa perceived usefulness berpengaruh signifikan terhadap purchase intention.

\section{Peran Perceived Value terhadap Hubungan Endorser dan Purchase Intention}

Hasil analisis startistik menunjukkan bahwa perceived value mampu memediasi sebagian (partial mediation) hubungan antara kredibilitas endorser terhadap purchase intention. Hal ini menyatakan bahwa persepsi nilai yang dirasakan oleh konsumen pada produk makanan mampu meningkatkan kepercayaannya terhadap kredibilitas food vlogger dan minat pembelian pada makanan yang direkomendasikan.

Persepsi nilai yang baik atas kualitas makanan yang diulas oleh endorser menjadikan konsumen minat untuk melakukan pembelian makanan. Perceived value konsumen tercipta dari akumulasi pengetahuan yang mereka dapatkan dari informasi endorser. Konsumen akan membandingkan persepsi kualitas dengan pengorbanan yang mereka lakukan untuk mendapatkan produk tersebut. Nilai yang dirasakan konsumen digunakan untuk mempertimbangkan aspek layanan dan biaya yang ditawarkan beberapa produk dari pesaing. Peranan endorser dalam memberikan pengetahuan dan informasi tentang produk, mengkomunikasikan manfaat produk, mewakili citra produk, serta membujuk konsumen membentuk perceived value konsumen terhadap suatu produk. Lebih lanjut, perceived value dapat mempengaruhi purchase intention konsumen dalam pembelian (Netemeyer et al., 2004; Petrick dan Backman, 2002). Hal tersebut membuat variabel perceived value mampu memediasi hubungan endorser terhadap minat beli konsumen secara signifikan. 
Peran Perceived Usefulness terhadap Hubungan Endorser dan Purchase Intention

Penggunaan YouTube sebagai media endorserment mempermudah konsumen dalam mendapatkan informasi berkaitan dengan alternatif pilihan makanan. Ulasan yang disampaikan oleh food vlogger terhadap produk makanan mampu mempunyai efek yang positif dalam mempromosikan suatu produk diyakini mampu mempermudah konsumen dalam mengingatnya. Sehingga keberadaan food vlogger mampu meningkatkan persepsi manfaat yang dirasakan konsumen dalam mencari informasi dan rekomendasi makanan. Lebih lanjut lagi, perceived usefulness yang dirasakan konsumen dari informasi yang diberikan oleh endorser mampu mendorong terbentuknya purchase intention. Konsumen cenderung memiliki minat untuk membeli makanan yang direkomendasikan oleh food vlogger dibanding mencoba makanan yang tidak pernah mereka beli. Ulasan yang disampaikan bermanfaat dalam meningkatkan persepsi kualitas dan nilai dari suatu makanan. Oleh karenanya, perceived usefulness berperan sebagai mediator penuh hubungan endorser terhadap purchase intention.

\section{Kesimpulan}

Kredibilitas seorang endoser yang ditunjukkan dengan attractiveness, trustworthiness dan level of expertise dari food vlogger dalam mengulas makanan tidak memiliki pengaruh yang signifikan terhadap purchase intention. Artinya peran endorser atau food vlogger dalam mengulas makanan yang ditayangkan pada akun YouTube mereka tidak signifikan membuat para pengikutnya untuk melakukan pembelian pada makanan yang mereka ulas. Akan tetapi peran endorser secara langsung meningkatkan perceived value dan perceived usefulness yang dirasakan oleh konsumen. Persepsi nilai yang baik atas kualitas makanan yang diulas oleh endorser menjadikan konsumen minat untuk melakukan pembelian makanan. Hal tersebut membuat variabel perceived value mampu memediasi hubungan endorser terhadap minat beli konsumen secara signifikan.

Penggunaan YouTube sebagai media endorserment mempermudah konsumen dalam mendapatkan informasi berkaitan dengan alternatif pilihan makanan. Keberadaan food vlogger mampu meningkatkan persepsi manfaat yang dirasakan konsumen dalam mencari informasi dan rekomendasi makanan. Dengan kata lain, endorser mampu meningkatkan perceived usefulness yang dirasakan oleh konsumen. Lebih lanjut lagi, perceived usefulness yang dirasakan konsumen dari informasi yang diberikan oleh endorser secara signifikan mampu mendorong terbentuknya purchase intention. Hal ini pula yang menyebabkan perceived usefulness secara signifikan dapat memediasi hubungan antara kredibilitas endorser terhadap minat beli konsumen.

\section{DAFTAR PUSTAKA}

Amos, C., Holmes, G., \& Strutton, D. (2008). Exploring The Relationship Between Celebrity Endorser Effects and Advertising Effectiveness. International Journal Of Advertising. Https://Doi.Org/10.1080/02650487.2 008.11073052

Belch, G. E., \& Belch, M. A. (2013). A Content Analysis Study of The Use Of Celebrity Endorsers in Magazine Advertising. International Journal of Advertising. Https://Doi.Org/10.2501/IJA-32-3369-389

Chi, H., Yeh, H., \& Tsai, Y. (2011). The Influences of Perceived Value on Consumer Purchase Intention: The Moderating Effect of Advertising Endorser. Journal of International Management Studies.

Dhar, R., \& Khan, U. (2006). Licensing Effect in Consumer Choice. Journal of Marketing Research,.

Erdogan, B. Z., Baker, M. J., \& Tagg, S. (2001). Selecting Celebrity Endorsers: The Practitioner's Perspective. in Journal of Advertising Research. Https://Doi.Org/10.2501/JAR-41-3- 
39-48

Ferdinand, P. D. A. (2016). Metode Penelitian Manajemen: Pedoman Penelitian Untuk Skripsi, Tesis Dan Disertasi Ilmu Manajemen. In BP Undip 2. Https://Doi.Org/10.4304/Jcp.8.2.326333

Gupta, D. R., Kishore, N., \& Verma, D. (2015). Impact of Celebrity Endorsements on Consumers' Purchase Intention: A Study of Indian Consumers. Australian Journal of Business And Management Research.

Hair, Jr, J. F. (2015). Essentials Of Business Research Methods. In Essentials of Business Research Methods. Https://Doi.Org/10.4324/9781315704 562

Han, E., \& Ki, E. J. (2010). Developing A Measure of Celebrity Reputation. Public Relations Review. Https://Doi.Org/10.1016/J.Pubrev.20 09.10 .013

Hsu, H. Y., \& Tsou, H. T. (2011). Understanding Customer Experiences in Online Blog Environments. International Journal Of Information Management.

Https://Doi.Org/10.1016/J.Ijinfomgt. 2011.05 .003

Keller, K. L. (2008). Strategic Brand Management: Building, Measuring, and Managing Brand (4th Edition). In Pearson/Prentice Hall. Https://Doi.Org/10.2307/1252315

Kim, S. S., Lee, J., \& Prideaux, B. (2014). Effect of Celebrity Endorsement on Tourists' Perception of Corporate Image, Corporate Credibility and Corporate Loyalty. International Journal of Hospitality Management. Https://Doi.Org/10.1016/J.Ijhm.2013. 11.003

Kok Wei, K., \& Li, W. Y. (2013). Measuring The Impact of Celebrity Endorsement on Consumer Behavioural Intentions: A Study of Malaysian Consumers. International Journal of Sports Marketing and Sponsorship. Https://Doi.Org/10.1108/Ijsms-14-
03-2013-B002

Kotler, P., \& Keller, K. L. (2009). Marketing Management (13th Ed.). In Prentice Hall.

Mcknight, H., Kacmar, C., \& Choudhury, V. (2003). Whoops... Did I Use The Wrong Concept to Predict ECommerce Trust? Modeling The Risk-Related Effects of Trust Versus Distrust Concepts. Proceedings of The 36th Annual Hawaii International Conference on System Sciences, HICSS 2003. Https://Doi.Org/10.1109/HICSS.2003 .1174393

Mir, I. A., \& Rehman, K. U. (2013). Factors Affecting Consumer Attitudes and Intentions Toward User-Generated Product Content on Youtube. Management \& Marketing.

Mohammad, A. A. S. (2012). The Effect of Brand Trust and Perceived Value in Building Brand Loyalty. International Research Journal of Finance and Economics.

Mohd, S. (2016). Green Product Purchase Intention: Impact of Green Brands, Attitude, and Knowledge. British Food Journal.

Ohanian, R. (1990). Construction and Validation of A Scale To Measure Celebrity Endorsers' Perceived Expertise, Trustworthiness, and Attractiveness. Journal of Advertising.

Https://Doi.Org/10.1080/00913367.1 990.10673191

Pavlou, P. A., \& Fygenson, M. (2006). Understanding and Predicting Electronic Commerce Adoption: An Extension of The Theory of Planned Behavior. MIS Quarterly: Management Information Systems. Https://Doi.Org/10.2307/25148720

Qureshi, M. M., \& Malik, H. M. (2017). The Impact of Celebrity Endorsement On Consumer Buying Behavior. Advances in Social Sciences Research Journal, 4(3), 159-170. Https://Doi.Org/10.14738/Assrj.43.26 
05

Renton, K., \& Renton, K. (2006). Florida State University Libraries The Relationship of Celebrity Advertisements To Consumer Attitudes And Purchases Intentions.

Roy, S. (2018). Meaning Transfer In Celebrity Endorsements: An Explanation Using Metaphors. Journal of Marketing Communications.

Https://Doi.Org/10.1080/13527266.2 016.1197294

Saxena, A. (2011). Blogs and Their Impact on Purchase Intention: A Structural Equation Modelling Approach. Paradigm.

Https://Doi.Org/10.1177/0971890720 110114

Sertoglu, A. E., Catli, O., \& Korkmaz, S. (2014). Examining The Effect of Endorser Credibility on The Consumers' Buying Intentions: An Empirical Study In Turkey. 4(1), 6677.

Subagio, D. P. W., Mugiono, M., \& Hadiwidjojo, D. (2018). Pengaruh Perceived Ease of Use Terhadap Repurchase Usefulness dan Trust Sebagai Variabel Mediasi. Jurnal Manajemen dan Kewirausahaan. Https://Doi.Org/10.26905/Jmdk.V6i1 .2067

Thompson, R. L., Higgins, C. A., \& Howell, J. M. (1991). Personal Computing: Toward A Conceptual Model Of Utilization. MIS Quarterly: Management Information Systems. Https://Doi.Org/10.2307/249443

Vidyanata, D., Sunaryo. Hadiwidjojo, D. (2018). Credibility As A Mediator of The Celebrity Endorsement Strategy To Generate. Journal of Applied Management, 16(3), 402-411.

Vidyanata, D., Sunaryo, S., \& Hadiwidjojo, D. (2018). The Role of Brand Attitude and Brand Credibility As A Mediator of The Celebrity Endorsement Strategy To Generate Purchase Intention. Jurnal Aplikasi
Manajemen, 16(3), 402-411. Https://Doi.Org/10.21776/Ub.Jam.20 18.016.03.04

Wang, Y. S., Wang, Y. M., Lin, H. H., \& Tang, T. I. (2003). Determinants of User Acceptance of Internet Banking: An Empirical Study. International Journal of Service Industry Management.

Https://Doi.Org/10.1108/0956423031 0500192

Wilcox, K., Kramer, T., \& Sen, S. (2011). Indulgence or Self-Control: A Dual Process Model of The Effect of Incidental Pride on Indulgent Choice. Journal of Consumer Research. Https://Doi.Org/10.1086/657606

Wilcox, K., \& Stephen, A. T. (2013). Are Close Friends The Enemy? Online Social Networks, Self-Esteem, and Self-Control. Journal of Consumer Research.

Https://Doi.Org/10.1086/668794

Yuksel, H. F. (2016). Factors Affecting Purchase Intention in Youtube Videos. Youtube Videolarinda Satin AlniYetiNiEtkiLeyen Faktörler. 